\title{
Anti-Inflammatory Activity of Constituents Isolated from Ulmus davidiana var. japonica
}

\author{
Ming Shan ZhenG ${ }^{1,2}$, Ju Hye YANG ${ }^{1}$, Ying $L^{1}$, Xian $L_{1}^{1}$, Hyeun Wook $\mathrm{CHANG}^{1}$, and Jong-Keun Son ${ }^{1, *}$ \\ ${ }^{1}$ College of Pharmacy, Yeungnam University, Gyeongsan 712-749, Republic of Korea, \\ ${ }^{2}$ College of Pharmacy, Yanbian University, Yanji 133000, P.R. China
}

(Received May 31, 2010; Revised July 12, 2010; Accepted July 15, 2010)

\begin{abstract}
Twenty six compounds (1-26) were isolated from the root barks of Ulmus davidiana var. japonica. The anti-inflammatory activity of the isolated compounds were evaluated against the generation of inflammatory chemical mediators in bone marrow-derived mast cells. Among them, compounds 10, 11, 13, 15 and 19 inhibited not only cyclooxygenase-2 dependent prostaglandin $D_{2}$ generation but also 5 -lipoxygenase dependent leukotrien $\mathrm{C}_{4}$ generation in a concentration-dependent manner. In addition, compounds 11,12 , 13,15 and 19 also inhibited $\beta$-hexosaminidase release, a marker of mast cell degranulation reaction, from bone marrow-derived mast cell. These results suggest that the anti-inflammatory activity of $U$. davidiana might in part occur by both the inhibition of eicosanoid generations and the degranulation reaction of mast cells.
\end{abstract}

Keywords: Ulmus davidiana var. japonica, Bone marrow-derived mast cells, Cyclooxygenase-2, 5Lipoxygenase, $\beta$-hexosaminidase, Anti-inflammatory activity

\section{INTRODUCTION}

Eicosanoids such as prostaglandins (PGs) and leukotriens (LTs) are major inflammatory lipid mediators (Gulliksson et al., 2006). These mediators are biosynthesized by cyclooxygenases (COX) and lipoxygenases (LOX) in many cell types and deeply associated with many inflammatory disorders. The enzyme responsible for PG synthesis exists as two isoforms, COX-1 (constitutive isoform) and COX-2 (inducible form) (Mitchell and Warner, 2006). Several COX-2 inhibitors have been developed and clinically prescribed showing less side effects (Rouzer and Marnett, 2009). Arachidonic acid can also be converted to leukotrienes (LTs) by the action of 5-lipoxygenase (5LOX). Therefore, the development of dual inhibitors that can simultaneously inhibit COX-2 and 5-LOX might enhance their individual anti-inflammatory effects and reduce the undesirable side effects that are associated with nonsteroidal anti-inflammatory drugs (NSAIDs) (Martel-Pelletier et al., 2003; Theoharides et al., 2007). Histamine released from mast cells is stored in secretory granules. The

${ }^{*}$ Corresponding author

Tel: +82-53-810-2817 Fax: +82-53-810-4654

E-mail: jkson@yu.ac.kr release of histamine and other pharmacological mediator from mast cells is a prominent feature of acute inflammatory processes including the immediate type anaphylactic reactions. There are various agents to induce the mast cell degranulation, which are commonly associated with the anaphylactic shocks in human and other mammals (Jippo et al., 2009; Metcalfe et al., 2009; Ono et al., 2009).

U. davidiana var. japonica (Ulmaceae) is a deciduous tree that is widely distributed in Korea, China and Japan. The barks of the stem and root of this plant have been used in the treatment of oedema, mastitis, gastric cancer, and inflammation (Jun et al., 1998). Anticancer, antiviral, antibacterial, and anti-inflammatory properties have also been reported (Jun et al., 1998; Jin et al., 2006, 2008; Kang et al., 2006; Suh et al., 2007). The solvent extract of $U$. davidiana has been reported to have anti-inflammatory activity on collagen-induced inflammation in rats and cyclooxygenase-2 (COX-2) (Song et al, 2006; Jin et al., 2008).

In the course of searching for anti-inflammatory compounds from plant sources, we found that the methanol $(\mathrm{MeOH})$ extract of the root barks of $U$. davidiana var. japonica displays potent inhibitory effects on COX-2, 5-lipoxygenase (5-LOX) and degranulation. This paper de- 
scribes inhibitory effects of the isolated compounds on not only generations of both COX-2 dependent $\mathrm{PGD}_{2}$ and 5 -LOX dependent $\mathrm{LTC}_{4}$ but also $\beta$-hexosaminidase release, a marker of mast cell degranulation reaction, from bone marrow-derived mast cell.

\section{MATERIALS AND METHODS}

\section{Plant material}

Root bark of $U$. davidiana var. japonica was purchased in February 2007 at a folk medicine market, "Yak-ryong-si", in Daegu, Republic of Korea. The preparations were confirmed taxonomically by Professor Ki-Hwan Bae, Chungnam National University, Daejeon, Republic of Korea. A voucher specimen (YNUD-2007) has been deposited at the College of Pharmacy, Yeungnam University.

\section{Instruments and reagents}

Optical rotations were measured using a model DIP-1000 automatic digital polarimeter (Jasco, Tokyo, Japan). Nuclear magnetic resonance (NMR) spectra were recorded on a $250 \mathrm{MHz}$ spectrometer (DMX 250, Bruker, Germany) using manufacturer's standard pulse program. Samples were dissolved in deuterated chloroform $\left(\mathrm{CDCl}_{3}-d_{1}\right)$, pyridine- $d_{5}$ or deuterated methanol $\left(\mathrm{CD}_{3} \mathrm{OD}\right)$, with chemical shifts reported in ppm downfield from tetramethylsilane (TMS). Fast atom bombardment mass spectrometry (FABMS) was performed using a model JMS700 spectrometer (Jeol, Tokyo, Japan). The stationary phases used for column chromatography (Silica gel 60, 70-230 and 230-400 mesh, Lichroprep RP-18 gel, 40-63 $\mu \mathrm{m}$, Sephadex ${ }^{\mathrm{TM}}$ LH-20) and thin layer chromatography (TLC) plates (Silica-gel $60 \mathrm{~F}_{254}$ and RP-18 $F_{254}, 0.25 \mathrm{~mm}$ ) were purchased from Merck $\mathrm{KGaA}$ (Darmstadt, Germany). Spots were detected under ultraviolet (UV) radiation and by spraying with $10 \% \mathrm{H}_{2} \mathrm{SO}_{4}$, followed by heating. High pressure liquid chromatography was performed using a LC-20AD pump and SPD- 20A UV/VIS detector (both from Shimadzu, Tokyo, Japan). All other chemicals and solvents were analytical grade and used without further purification.

\section{Extraction and isolation}

Preparations of $U$. davidiana dried root bark $(10 \mathrm{~kg})$ were extracted three times with $13 \mathrm{~L}$ of $70 \% \mathrm{MeOH}$ by reflux. The dried $\mathrm{MeOH}$ extract $(1.1 \mathrm{~kg})$ was suspended in distilled $1.4 \mathrm{~L}$ water and the solution was successively partitioned with $n$-hexane $(1.4 \mathrm{~L} \times 3)$, ethyl acetate (EtOAc, 1.4 $\mathrm{L} \times 3)$ and $n$-butanol $(n-\mathrm{BuOH}, 1.4 \mathrm{~L} \times 3)$. After drying, four solvent extracts were obtained: $n$-hexane $(67.6 \mathrm{~g})$, EtOAc (70.5 g), $n$-BuOH (320 g) and $\mathrm{H}_{2} \mathrm{O}(555 \mathrm{~g})$. The $n$-hexane extract $(67 \mathrm{~g})$ was applied to a silica gel column $(60 \times 11$ $\mathrm{cm}$, No.9385, 230-400 mesh, Merck, Germany) and the column was eluted in a stepwise gradient mode with from $100 \% n$-hexane to $100 \%$ EtOAc, and (from $100 \%$ EtOAc to $100 \% \mathrm{MeOH}$. Fractions were combined based on TLC analysis. Thirty-four fractions (UDH1-34) were obtained. Fractions UDH1, UDH3, UDH6, UDH9, UDH11, UDH22, UDH31 and UDH34 yielded compounds 1 ( $80 \mathrm{mg}), 2$ (120 $\mathrm{mg}), 3$ (100 mg), 4 (20 mg), $5(1 \mathrm{~g}), 6(20 \mathrm{mg}), 11(33 \mathrm{mg})$ and $7(1.5 \mathrm{~g})$, respectively. Fraction UDH27 $(1.0 \mathrm{~g})$ was further separated into five fractions (UDH27-1-UDH27-5) by Sephadex LH- 20 column $(3 \times 90 \mathrm{~cm}, 1 \mathrm{~L})$ chromatography, and eluted with $\mathrm{CHCl} 3: \mathrm{MeOH}(4: 6)$. Compound 10 $(8 \mathrm{mg})$ was obtained from UDH27-2 using a LiChroprep RP-18 reverse-phase column $(4 \times 50 \mathrm{~cm})$ with elution by $\mathrm{MeOH}-\mathrm{H}_{2} \mathrm{O}$ (gradient from $70: 30$ to $100 \% \mathrm{MeOH}$ ). Fraction UDH23 (300 mg) was applied to a Sephadex LH-20 column $(3 \times 90 \mathrm{~cm}, 1 \mathrm{~L})$ and eluted with $100 \% \mathrm{MeOH}$ to give 8 (30 mg). Compound $9(27 \mathrm{mg}$ ) was obtained from UDH30 by elution through a Sephadex LH-20 column $(3 \times 90 \mathrm{~cm}$, $0.5 \mathrm{~L}$ ) with $\mathrm{MeOH}$ and a LiChroprep RP-18 reverse-phase column $(4 \times 50 \mathrm{~cm})$ with $\mathrm{MeOH}-\mathrm{H}_{2} \mathrm{O}$ (gradient from 80:20 to $100 \% \mathrm{MeOH}$ ), successively. Fraction UDH18 (100 mg) was applied to a $4 \times 50 \mathrm{~cm}$ LiChroprep RP-18 reversephase column with $\mathrm{MeOH}-\mathrm{H}_{2} \mathrm{O}$ (gradient from $80: 20$ to $100 \% \mathrm{MeOH}$ ) to give $12(14.5 \mathrm{mg}$ ).

The EtOAc extract $(65 \mathrm{~g})$ was applied to a silica gel column (9×60 cm, NO. 9385, 230-400 mesh, Merck, Germany), and eluted with a gradient of methylene chloride $\left(\mathrm{CH}_{2} \mathrm{Cl}_{2}\right)$ $\mathrm{MeOH}$ (from $100 \% \mathrm{CH}_{2} \mathrm{Cl}_{2}$ to $100 \% \mathrm{MeOH}$ ). The eluates were combined based on TLC, giving 29 fractions (UDE129). Compound 13 ( $30 \mathrm{mg}$ ) was obtained from UDE20 by Sephadex LH20 columns $(3 \times 90 \mathrm{~cm}, 1 \mathrm{~L})$ with isocratic elution $(100 \% \mathrm{MeOH})$. Fraction UDE26 was further chromatographed using Sephadex LH20 column $(3 \times 90 \mathrm{~cm}, 1 \mathrm{~L})$ with isocratic elution $(100 \% \mathrm{MeOH})$ to obtain $14(500 \mathrm{mg})$ and fractions UDE26-1-UDE26-3. Fraction UDE26-3 purified by a $4 \times 50 \mathrm{~cm}$ LiChroprep RP-18 reverse-phase column with $\mathrm{MeOH}-\mathrm{H}_{2} \mathrm{O}$ gradient elution (from $10-100 \% \mathrm{MeOH}$ ) to yield compounds $15(32 \mathrm{mg})$ and $16(25 \mathrm{mg})$.

An $n-\mathrm{BuOH}$ extract $(150 \mathrm{~g})$ was applied into a column packed with silica gel $(9 \times 60 \mathrm{~cm}$, No. 9385, 230-400 mesh, Merck, Germany) and eluted with $\mathrm{CH}_{2} \mathrm{Cl}_{2}-\mathrm{MeOH}$ (gradient from $100 \% \mathrm{CH}_{2} \mathrm{Cl}_{2}$ to $100 \% \mathrm{MeOH}$ ) and 30 fractions (UDB1UDB30) were acquired. Fraction UDB11 was further purified to give $17(45 \mathrm{mg})$ by elution with a $4 \times 50 \mathrm{~cm}$ LiChroprep RP-18 reverse-phase column with $10 \% \mathrm{MeOH}$. Compounds, $20(20 \mathrm{mg}), 24(16 \mathrm{mg}), 18(11.6 \mathrm{mg})$ and $19(5 \mathrm{mg})$ were obtained from UDB15 using repeated chromatography with a $4 \times 50 \mathrm{~cm}$ LiChroprep RP-18 column. Fraction UDB16 
was further separated into compounds $21(8 \mathrm{mg}, 55.2$ $\mathrm{min}$ ), 22 (39.8 mg, $44.4 \mathrm{~min}$ ) and 23 ( $23 \mathrm{mg}, 50.3 \mathrm{~min}$ ) by HPLC (Inertsil ${ }^{\circledR}$ ODS-3 $250 \times 4.6 \mathrm{~mm}, 5 \mu \mathrm{m}$, GL Science, Japan) with isocratic elution with $\mathrm{MeOH}-\mathrm{H}_{2} \mathrm{O}$ (33:67). Compounds $25(17 \mathrm{mg})$ and $26(26.5 \mathrm{mg})$ were obtained from UDB23 by successive chromatography with a Sephadex LH20 column $(3 \times 90 \mathrm{~cm}, 1 \mathrm{~L})$ with isocratic elution $(100 \%$ $\mathrm{MeOH}$ ), and a $4 \times 50 \mathrm{~cm}$ LiChroprep RP-18 reverse-phase column with $10 \% \mathrm{MeOH}$.

\section{4-Ethylcholesta-5,22-dien-3 $\beta$-ol-palmitic acid ester (1)}

Colorless needles; $\left.[\alpha]_{\mathrm{D}}^{25}-69^{\circ}(c) 0.1, \mathrm{CHCl}_{3}\right) ;{ }^{1} \mathrm{H}-$ and ${ }^{13} \mathrm{C}$-NMR data were consistent with the literature values (Wang et al., 2006); FABMS m/z 673.6 [M+ Na] ${ }^{+}$.

\section{Friedelin (2)}

Colorless needles; $[\alpha]_{\mathrm{D}}^{25}-59^{\circ}\left(\mathrm{c} 0.1, \mathrm{CHCl}_{3}\right) ;{ }^{1} \mathrm{H}$ - and ${ }^{13} \mathrm{C}$-NMR data were consistent with the literature values (Ali et al., 1999); FABMS $\mathrm{m} / \mathrm{z} 426.7$ [M] ${ }^{+}$.

\section{Epifriedelanol (3)}

White crystals; $[\alpha]_{\mathrm{D}}^{25} 47^{\circ}$ (c $\left.0.1, \mathrm{CHCl}_{3}\right) ;{ }^{1} \mathrm{H}-$ and ${ }^{13} \mathrm{C}$ NMR data were consistent with the literature values ( $\mathrm{Li}$ et al., 2007); FABMS $\mathrm{m} / \mathrm{z} 427$ [M-H] .

\section{Eicosanoic acid (4)}

White powder; ${ }^{1} \mathrm{H}$ - and ${ }^{13} \mathrm{C}$-NMR data were consistent with the literature values (Chung et al., 2007); FABMS $\mathrm{m} / \mathrm{z}$ $312.5[\mathrm{M}]^{+}$.

\section{$\beta$-Sitosterol (5)}

White crystals; $[\alpha]_{\mathrm{D}}^{25}-36^{\circ}\left(\mathrm{c} 0.1, \mathrm{CHCl}^{3}\right) ;{ }^{1} \mathrm{H}$ - and ${ }^{13} \mathrm{C}$ NMR data were consistent with the literature values (Umlauf et al., 2004); FABMS m/z 414.4 [M] ${ }^{+}$.

\section{Betulinic acid (6)}

White crystals; $[\alpha]_{\mathrm{D}}^{25}+9^{\circ}\left(\mathrm{c} \quad 0.1, \mathrm{CHCl}_{3}\right) ;{ }^{1} \mathrm{H}$ - and ${ }^{13} \mathrm{C}$ NMR data were consistent with the literature values (Aguirre et al., 2006); FABMS m/z $456.7\left[\mathrm{M}^{+}\right.$.

\section{Sitosterol-3- 0 - $\beta$-D-glucoside (7)}

Brown soild; $[\alpha]_{\mathrm{D}}^{25}-51^{\circ}\left(c \quad 0.1, \mathrm{CHCl}_{3}\right) ;{ }^{1} \mathrm{H}$ - and ${ }^{13} \mathrm{C}$ NMR data were consistent with the literature values (Sang et al., 2002); FABMS $\mathrm{m} / \mathrm{z} 576.4[\mathrm{M}]^{+}$.

\section{Oleanolic acid (8)}

White crystals; $[\alpha]_{\mathrm{D}}^{25}+65^{\circ}\left(\mathrm{c} 0.1, \mathrm{CHCl}_{3}\right) ;{ }^{1} \mathrm{H}$ - and ${ }^{13} \mathrm{C}$ NMR data were consistent with the literature values (Seebacher et al., 2003); FABMS m/z $438.3[\mathrm{M}-\mathrm{OH}]^{+}$.

\section{Maslinic acid (9)}

White powder; $[\alpha]_{\mathrm{D}}^{25}+60^{\circ}\left(\mathrm{c} 0.1, \mathrm{CHCl}_{3}\right) ;{ }^{1} \mathrm{H}$ - and ${ }^{13} \mathrm{C}$ NMR data were consistent with the literature values (Hisashi and Haruo, 1989); FABMS m/z 472.3 [M] $^{+}$.

\section{Stigmast-5-ene-3 $\beta, 4 \alpha$-diol (10)}

White powder; ${ }^{1} \mathrm{H}$ - and ${ }^{13} \mathrm{C}-\mathrm{NMR}$ data were consistent with the literature values (Yumiko et al., 1995; Siddiqui et al., 2006); FABMS $\mathrm{m} / \mathrm{z} 430.3$ [M] $^{+}$.

\section{3-O-(6-O-Palmitoryl)- $\beta$-D-glucopyranosyl stigmasterol} (11)

White powder; $[\alpha]_{\mathrm{D}}^{25}-25.4^{\circ}$ (c 0.1 pyridine); ${ }^{1} \mathrm{H}$ - and ${ }^{13} \mathrm{C}$ NMR data were consistent with the literature values (Lavaud et al., 1994); FABMS m/z 835.6 [M+Na] ${ }^{+}$.

\section{Acorusnol (12)}

Viscous oil; ${ }^{1} \mathrm{H}$ - and ${ }^{13} \mathrm{C}$-NMR data were consistent with the literature values (Nawamaki and Kuroyanagi, 1996); FABMS $m / z 236.1[\mathrm{M}]^{+}$.

\section{(-)-Catechin (13)}

Brown amorphous powder; $[\alpha]_{\mathrm{D}}^{25}$ : $-20.5^{\circ}(c 0.2 \mathrm{MeOH})$; ${ }^{1} \mathrm{H}$ - and ${ }^{13} \mathrm{C}$-NMR data were consistent with the literature values (Nahrstedt et al., 1987); FABMS m/z 290.1 [M] $^{+}$.

\section{Catechin-7-O- $\beta$-apiofuranoside (14)}

Colorless needles; $[\alpha]_{\mathrm{D}}^{25}:+31.6^{\circ}(c 0.1 \mathrm{MeOH}) ;{ }^{1} \mathrm{H}-$ and ${ }^{13} \mathrm{C}$-NMR data were consistent with the literature values ( $\mathrm{Na}$ et al., 2002); FABMS m/z $423.1[\mathrm{M}+\mathrm{H}]^{+}$.

\section{Catechin-7- 0 - $\alpha$-L-rhamnopyranoside (15)}

Yellowish amorphous solid; $[\alpha]_{\mathrm{D}}^{25}$ : $-96.1^{\circ}(c 0.1 \mathrm{MeOH})$; ${ }^{1} \mathrm{H}$ - and ${ }^{13} \mathrm{C}$-NMR data were consistent with the literature values (Moon and Rim, 1995); FABMS m/z $436.1[\mathrm{M}]^{+}$.

\section{Catechin-3- 0 - $\alpha$-L-rhamnopyranoside (16)}

Colorless needles; $[\alpha]^{25}$ : $-56.4^{\circ}(c 0.1 \mathrm{MeOH}) ;{ }^{1} \mathrm{H}$ - and ${ }^{13} \mathrm{C}$-NMR data were consistent with the literature values (Ishimaru et al., 1987); FABMS $\mathrm{m} / \mathrm{z} 437.2[\mathrm{M}+\mathrm{H}]^{+}$.

\section{Butyl $\alpha$-D-fructofuranoside (17)}

Amorphous powder; $[\alpha]_{\mathrm{D}}^{25}$ : $+31.0^{\circ}$ (c $\left.0.2 \mathrm{MeOH}\right) ;{ }^{1} \mathrm{H}-$ and ${ }^{13} \mathrm{C}$-NMR data were consistent with the literature values (Zhang et al., 1996); FABMS $\mathrm{m} / \mathrm{z} 259.1[\mathrm{M}+\mathrm{Na}]^{+}$.

\section{Ampelopsisionoside (18)}

White powder; $[\alpha]_{\mathrm{D}}^{25}-32.5^{\circ}(c \quad 0.01, \mathrm{MeOH}) ;{ }^{1} \mathrm{H}$ - and ${ }^{13} \mathrm{C}$-NMR data were consistent with the literature values (Pabst et al., 1992); FABMS m/z $411.2[\mathrm{M}+\mathrm{Na}]^{+}$. 


\section{cis-Roseoside (19)}

Colorless needles; $[\alpha]_{\mathrm{D}}^{25}$ : $-60^{\circ}(c 0.01 \mathrm{MeOH}) ;{ }^{1} \mathrm{H}$ - and

${ }^{13} \mathrm{C}$-NMR data were consistent with the literature values (Pabst et al., 1992); FABMS $\mathrm{m} / \mathrm{z} 409.2[\mathrm{M}+\mathrm{Na}]^{+}$.

\section{(+)-5-Methoxyisolariciresinol-9-O- $\beta-D-x y l o p y r a n o s i d e$} (20)

Yellowish amorphous powder; $[\alpha]_{D}^{25}:+35.1^{\circ}$ (c 0.01 , $\mathrm{MeOH}) ;{ }^{1} \mathrm{H}$ - and ${ }^{13} \mathrm{C}$-NMR data were consistent with the literature values (Lee et al., 2001); FABMS $m / z 522.2[\mathrm{M}]^{+}$.

\section{(+)-Isolariciresinol-9'-O- $\beta$-D-xylopyranoside (21)}

Colorless needles: $[\alpha]_{D}^{25}:+49.2^{\circ}(c 0.01 \mathrm{MeOH}) .{ }^{1} \mathrm{H}-$ and ${ }^{13} \mathrm{C}$-NMR data were consistent with the literature values (Lee et al., 2001); FABMS m/z 492.2 [M] ${ }^{+}$.

\section{Lyoniside (22)}

Colorless needles; $[\alpha]_{\mathrm{D}}^{25}:+23.5^{\circ}(c 0.2 \mathrm{MeOH}) ;{ }^{1} \mathrm{H}$ - and ${ }^{13} \mathrm{C}$-NMR data were consistent with the literature values (Inoshiri et al., 1987; Smite et al., 1995); FABMS m/z 552.3 $[\mathrm{M}]^{+}$.

\section{Nudiposide (23)}

Colorless needles; $[\alpha]_{\mathrm{D}}^{25}$ : $-32.5^{\circ}$ (c $\left.0.2 \mathrm{MeOH}\right) ;{ }^{1} \mathrm{H}$ - and ${ }^{13} \mathrm{C}$-NMR data were consistent with the literature values (Inoshiri et al., 1987; Smite et al., 1995); FABMS m/z 552.3 $[\mathrm{M}]^{+}$.

\section{Ssioriside (24)}

Yellow amorphous powder; $[\alpha]_{\mathrm{D}}^{25}+20.5^{\circ}(\mathrm{c} 0.1, \mathrm{MeOH})$; ${ }^{1} \mathrm{H}$ - and ${ }^{13} \mathrm{C}$-NMR data were consistent with the literature values (Yoshinari et al., 1989); FABMS $m / z 554.2[\mathrm{M}]^{+}$.

\section{Catechin-7- 0 - $\beta$-D-glucopyranoside (25)}

Colorless solid; $[\alpha]_{\mathrm{D}}^{25}$ : $-86.5^{\circ}(c 0.1 \mathrm{MeOH}) ;{ }^{1} \mathrm{H}$ - and

${ }^{13} \mathrm{C}$-NMR data were consistent with the literature values (Foo and Karchesy, 1989); FABMS $\mathrm{m} / \mathrm{z} 452.1$ [M] $^{+}$.

\section{Procyanidin B3 (26)}

Brown powder; $[\alpha]_{D}^{25}:-174.5^{\circ}(c 0.01 \mathrm{MeOH}) ;{ }^{1} \mathrm{H}$ - and ${ }^{13} \mathrm{C}$-NMR data were consistent with the literature values (Kohler et al., 2008); FABMS m/z 601.1 [M+Na] ${ }^{+}$.

\section{Preparation and activation of bone marrow-derived mast cells (BMMCs)}

Bone marrow cells from male Balb/cJ mice were cultured for up to 10 weeks in $50 \%$ enriched medium (RPMI 1,640 containing $2 \mathrm{mM}$ L-glutamine, $0.1 \mathrm{mM}$ nonessential amino acids, antibiotics and $10 \%$ fetal calf serum) and $50 \%$ WEHI- 3 cell conditioned medium as a source of inter- leukin (IL)-3. After 3 weeks, $>98 \%$ of the cells were BMMCs when checked as previously described (Murakami et al., 1994).

\section{Determination of prostaglandin $\mathrm{D}_{2}\left(\mathrm{PGD}_{2}\right)$}

In order to measure the inhibitory activity on COX-2 by samples, cells were suspended in enriched medium at a cell density of $5 \times 10^{5} \mathrm{cells} / \mathrm{ml}$ and preincubated with aspirin $(10 \mu \mathrm{g} / \mathrm{ml})$ for $2 \mathrm{~h}$ to irreversibly inactivate any preexisting COX-1. After washing, the BMMCs were activated with c-kit ligand (KL, $100 \mathrm{ng} / \mathrm{ml}), \mathrm{IL}-10(100 \mathrm{U} / \mathrm{ml})$ and lipopolysaccharide (LPS, $100 \mathrm{ng} / \mathrm{ml}$ ) at $37^{\circ} \mathrm{C}$ for $8 \mathrm{~h}$ in the presence or absence of samples previously dissolved in dimethylsulfoxide (DMSO). All reactions were quenched by centrifugation at $120 \mathrm{~g}$ at $4^{\circ} \mathrm{C}$ for $5 \mathrm{~min}$. The supernatant and cell pellets were frozen immediately in liquid $\mathrm{N}_{2}$ and stored at $-80^{\circ} \mathrm{C}$ until needed for further analysis. Concentrations of $\mathrm{PGD}_{2}$ in the supernatant were measured using a $\mathrm{PGD}_{2}$ assay kit (Cayman Chemical, Ann Arbor, MI, USA) according to the manufacturer's instructions. Under these conditions, the COX-2-dependent phases of $\mathrm{PGD}_{2}$ generation reached $1.6 \mathrm{ng} / 10^{6}$ cells. The data is reported as the arithmetic mean of triplicate determinations.

\section{Determination of leukotriene $\mathrm{C}_{\mathbf{4}}\left(\mathrm{LTC}_{\mathbf{4}}\right)$}

BMMCs suspended in the aforementioned enriched medium at a density of $1 \times 10^{6} \mathrm{cells} / \mathrm{ml}$ were pretreated with the samples for $15 \mathrm{~min}$ at $37^{\circ} \mathrm{C}$ and stimulated with $\mathrm{KL}$ (100 $\mathrm{ng} / \mathrm{ml}$ ). After $20 \mathrm{~min}$, the supernatants were retrieved and analyzed by enzyme immunoassay (EIA). The $\mathrm{LTC}_{4}$ level was determined using an enzyme immunoassay kit (Cayman Chemical, Ann Arbor, MI, USA) according to the manufacturer's instructions. Under these conditions, the $\mathrm{LTC}_{4}$ reached $5 \mathrm{ng} / 10^{6}$ cells. The data is reported as the arithmetic mean of triplicate determinations.

\section{Assay of $\beta$-HEX release}

$\beta$-HEX, a marker of mast cell degranulation, was quantified by spectrophotometric analysis of the hydrolysis of p-nitrophenyl-2-acetamido-2-deoxy- $\beta$-D-glucopyranoside (PNP-GluNAc, Sigma-Aldrich, St. Louis, MO, USA). Briefly, after harvesting supernatant, cells were lysed in the same volume of medium by three cycles of freezing and thawing. Ten milliliters of the BMMC lysate or supernatant samples were mixed with $50 \mu \mathrm{l}$ of $\beta$-HEX substrate solution (1.3 $\mathrm{mg} / \mathrm{ml}$ PNP-GluNAc in $100 \mathrm{mM}$ sodium citrate, $\mathrm{pH} 4.5$ ) in each well of 96 -well plates and then incubated at $37^{\circ} \mathrm{C}$ for $60 \mathrm{~min}$. The reaction was stopped by adding $140 \mu \mathrm{l}$ of 0.2 $\mathrm{M}$ Glycine- $\mathrm{NaOH}$ ( $\mathrm{pH}$ 10.7). The absorbance at $410 \mathrm{~nm}$ was measured in a microplate reader. The percentage of 
$\beta$-HEX released into the supernatant was calculated by the following formula: $[S /(S+P)] \times 100$, where $S$ and $P$ are the $\beta$-HEX contents of supernatant and cell pellet.

\section{RESULTS AND DISCUSSION}

During our search for biologically active compounds derived from endemic species in Korea, $\mathrm{MeOH}$ extracts of the roots of $U$. davidiana were demonstrated to possess COX-2 and 5-LOX dual inhibitory activities by assessing their effects on the production of the $\mathrm{PGD}_{2}$ and $\mathrm{LTC}_{4}$ in mouse BMMCs. Repeated normal-phase silica gel, reverse-phase, Sephadex LH-20 column chromatography and HPLC lead to the isolation of one fatty acid (4) and eleven terpens $(1-3,5-12)$ from the $n$-hexane extract; four flavonoids (13-16) from the EtOAc extract; and two flavonoids $(25,26)$, five lignans $(20-24)$, two butenyl clohexnone glycosides $(18,19)$ and one fructofuranoside (17) from the $\mathrm{n}-\mathrm{BuOH}$ extract (Fig. 1). Chemical structures of the isolated compounds were determined by comparison of optical rotation values, ${ }^{1} \mathrm{H}$ - and ${ }^{13} \mathrm{C}-\mathrm{NMR}$, and mass spectral data of each compound with those published.

The use of BMMCs as a model appears to be suitable for screening of selective COX-1/COX-2 or 5-LOX and COX-2/5-LOX dual inhibitors and degranulation inhibitors from various sources (Moon et al., 1999; Lee et al., 2004; Son et al., 2005; Jin et al., 2009). The generation of COX-2 dependent $\mathrm{PGD}_{2}$ and 5 -LOX dependent $\mathrm{LTC}_{4}$ were tested after activation of the BMMCs with a combination of KL, interleukin and LPS in the presence or absence of each compound. Compounds 10, 11, 13, 15 and 19 inhibited COX-2-dependent $\mathrm{PGD}_{2}$ generation with $\mathrm{IC}_{50}$ values of $30.8,12.6,4.7,17.0$ and $30.9 \mu \mathrm{M}$, respectively, and the generation of $\mathrm{LTC}_{4}$ in the 5-LOX dependent phase with $\mathrm{IC}_{50}$ values of $29.6,38.9,0.8,8.0$ and $10.3 \mu \mathrm{M}$, respectively (Table I). Compound 12 showed no inhibiton of COX-2-dependent $\mathrm{PGD}_{2}$ generation, but inhibited 5-LOX with an $\mathrm{IC}_{50}$ value of $11.8 \mu \mathrm{M}$. Licofelone, a dual inhibitor of
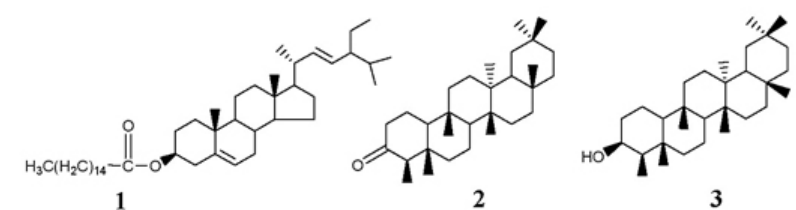

Hooc $\sim$

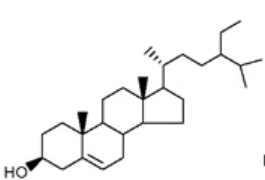

5

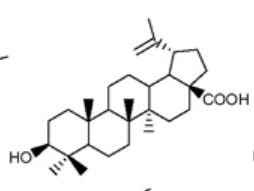

6

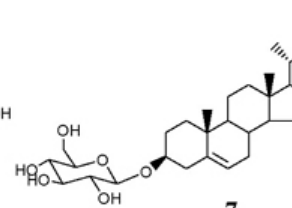

7

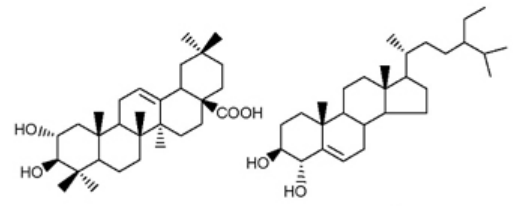

10

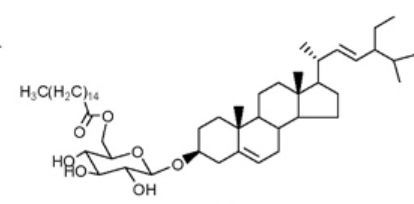

11
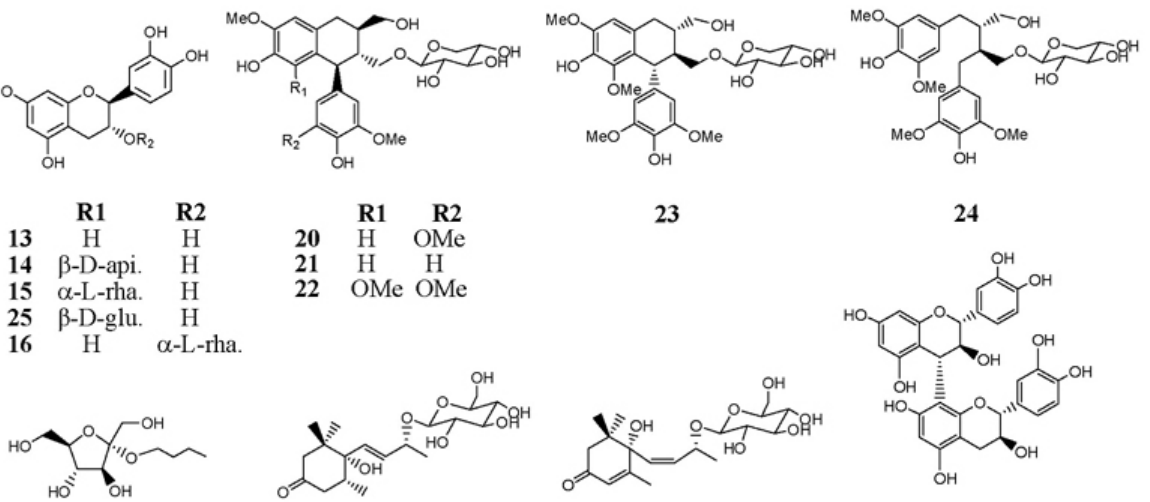

18

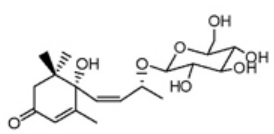

19

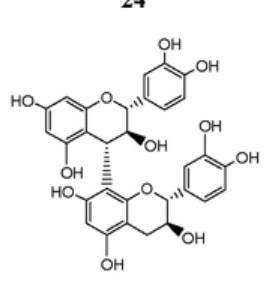

26
Fig. 1. Chemical structures of compounds 1-26 from Ulmus davidiana var. japonica. 
Table I. Anti-inflammatory activity of isolated compounds from Ulmus davidiana var. japonica.

\begin{tabular}{|c|c|c|c|c|c|c|}
\hline \multirow{3}{*}{ Compound } & \multicolumn{3}{|c|}{ Inhibition (\%) } & \multicolumn{3}{|c|}{ IC50 $(\mu \mathrm{M})$} \\
\hline & $\mathrm{PGD}_{2}$ & $\mathrm{LTC}_{4}$ & $\beta$-Hex & \multirow{2}{*}{$\mathrm{PGD}_{2}$} & \multirow{2}{*}{$\mathrm{LTC}_{4}$} & \multirow{2}{*}{$\beta$-Hex } \\
\hline & $20 \mu \mathrm{M}$ & $20 \mu \mathrm{M}$ & $25 \mu \mathrm{M}$ & & & \\
\hline 1 & 13.2 & 1.6 & 26.5 & - & - & - \\
\hline 2 & 15.1 & 0 & 31.3 & - & - & - \\
\hline 3 & 39.6 & 11.7 & 1.3 & - & - & - \\
\hline 4 & 9.0 & 0 & 30.6 & - & - & - \\
\hline 5 & 11.4 & 0 & 8.7 & - & - & - \\
\hline 6 & 0 & 0 & 0 & - & - & - \\
\hline 7 & 7.7 & 8.2 & 18.5 & - & - & - \\
\hline 8 & 9.3 & 35.7 & 0 & - & - & - \\
\hline 9 & 23.9 & 74.7 & 25.7 & - & 38.70 & - \\
\hline 10 & 60.6 & 63.6 & 0 & 30.8 & 29.59 & - \\
\hline 11 & 73.6 & 63.5 & 69.9 & 12.62 & 38.88 & 28.72 \\
\hline 12 & 31.7 & 81.4 & 78.9 & - & 11.84 & 82.38 \\
\hline 13 & 68.6 & 99.8 & 76.4 & 4.7 & 0.78 & 1.4 \\
\hline 14 & 3.4 & 0 & 0 & - & - & - \\
\hline 15 & 67.7 & 94.5 & 64.0 & 17.0 & 8.04 & 16.8 \\
\hline 16 & 0 & 12.5 & 46.3 & - & - & - \\
\hline 17 & 14.4 & 0 & 0.03 & - & - & - \\
\hline 18 & 0 & 0 & 3.4 & - & - & - \\
\hline 19 & 59.4 & 60.6 & 63.3 & 30.9 & 10.32 & 16.6 \\
\hline 20 & 1.8 & 0 & 0 & - & - & - \\
\hline 21 & 0 & 0 & 0 & - & - & - \\
\hline 22 & 0 & 0 & 0 & - & - & - \\
\hline 23 & 0 & 0 & 0 & - & - & - \\
\hline 24 & 0 & 0 & 0 & - & - & - \\
\hline 25 & 4.8 & 0 & 9.2 & - & - & - \\
\hline \multirow[t]{4}{*}{26} & 0 & 0 & 0 & - & - & - \\
\hline & \multirow{3}{*}{\multicolumn{2}{|c|}{$\begin{array}{l}\mathrm{PGD}_{2} \text { positive control } \\
\mathrm{LTC}_{4} \text { positive control } \\
\beta-\mathrm{Hex} \text { positive control }\end{array}$}} & Licofelone & 0.025 & - & - \\
\hline & & & Licofelone & - & 0.86 & - \\
\hline & & & DPT & - & - & 27.5 \\
\hline
\end{tabular}

(A)

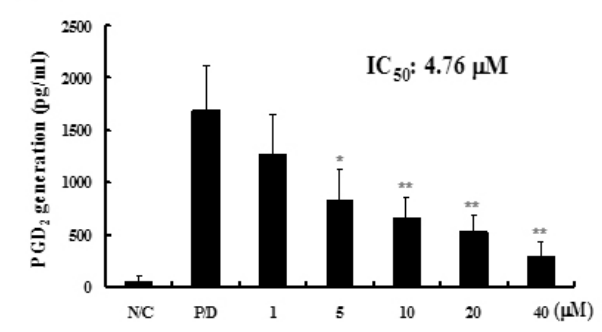

(B)

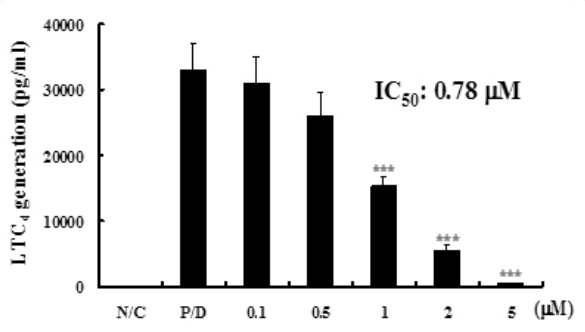

(C)

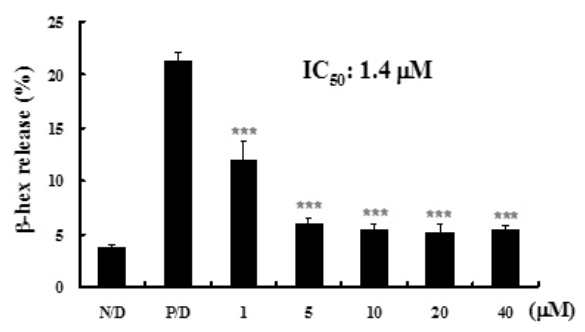

Fig. 2. Inhibitory effects of compound 13 on generations of $P G D_{2}(A)$ and $L T C_{4}(B)$, and degranulation reaction $(C)$ from bone marrow-derived mast cell. (A) BMMC were pre-incubated for 30 min with the indicated concentration of 13 and then stimulated with $\mathrm{KL}$ $(100 \mathrm{ng} / \mathrm{ml}), \mathrm{IL}-10(100 \mathrm{U} / \mathrm{ml})$ and LPS $(100 \mathrm{ng} / \mathrm{ml})$ at $37^{\circ} \mathrm{C}$ for $8 \mathrm{~h}$ in the presence or absence of $13 . P G D_{2}$ released into the supernatant was quantified by EIA kit. (B) BMMC were pre-incubated for 30 min with the indicated concentrations of 13 and then stimulated with 100 $\mathrm{ng} / \mathrm{ml}$ of $\mathrm{KL}$ for $15 \mathrm{~min}$. $\mathrm{LTC}_{4}$ released into the supernatant was quantified by EIA kit. (C) BMMC were pre-incubated for 30 min with the indicated concentrations of 13 and then stimulated with $100 \mathrm{ng} / \mathrm{ml}$ of $\mathrm{KL}$ for $15 \mathrm{~min}$. $\beta$-HEX released into the supernatant cell lysate was measured. The data represent the mean \pm S.D. of three different samples. ${ }^{*} p<0.05,{ }^{* *} p<0.01,{ }^{* * *} p<0.001$ versus control.

COX-2 and 5-LOX, was used as positive control $\left(\mathrm{IC}_{50}\right.$ of $0.025 \mu \mathrm{M}$ and $0.86 \mu \mathrm{M}$, respectively)(Boileau et al., 2002; Rotondo et al., 2002). These results clearly demonstrated that compounds $10,11,13,15$ and 19 have dual COX2/5-LOX inhibitory activity. In addition, 11, 12, 13, 15 and
19 also inhibited $\beta$-HEX release in BMMCs in a concentration-dependent manner with an $\mathrm{IC}_{50}$ of $28.7 \mu \mathrm{M}, 82.4$ $\mathrm{mM}, 1.4 \mathrm{mM}, 16.8 \mathrm{mM}$ and $16.6 \mathrm{mM}$, respectively, in comparison with the positive control deoxypodophyllotoxin (DPT) (Lee et al., 2004), which inhibited degranulation re- 
action in a dose-dependent manner in BMMCs $\left(\mathrm{IC}_{50}: 27.5\right.$ $\mu \mathrm{M})$. Among these compounds, 13 exhibited the strongest inhibitory effects not only on generation of $\mathrm{PGD}_{2}$ and $\mathrm{LTC} 4$ but also on $\beta$-HEX release in BMMCs (Fig. 2). The inhibitory activity of 13 on COX-2 activity in RAW 264.7 cells but no inhibitory activities on 5-LOX or $\beta$-HEX release of 13 has been reported (Kim et al., 2004).

In conclusion, compounds 10,11, 12, 13, 15 and 19 among those isolated from the roots of $U$. davidiana are principal compounds that inhibit COX-2-dependent $\mathrm{PGD}_{2}$ generation, 5-LOX-dependent $\mathrm{LTC}_{4}$ generation and $\beta$-HEX release in BMMCs. These results suggest that the anti-inflammatory activity of $U$. davidiana var. japonica might occur by both the inhibited generation of eicosanoids and obviated mast cell degranulation. Further studies are needed to investigate the mechanisms of action of the isolated compounds.

\section{ACKNOWLEDGMENTS}

This research was supported by the Yeungnam University research grant in 2008.

\section{REFERENCES}

Aguirre, M. C., Delporte, C., Backhouse, N., Erazo, S., Letelier, M. E., Cassels, B. K., Silva, X., Alegria, S. and Negrete, R. (2006). Topical anti-inflammatory activity of 2alpha-hydroxy pentacyclic triterpene acids from the leaves of Ugni molinae. Bioorg. Med. Chem. 14, 5673- 5677.

Ali, M. S., Mahmud, S., Perveen, S., Ahmad, V. U. and Rizwani, G. H. (1999). Epimers from the leaves of Calophyllum inophyllum. Phytochemistry. 50, 1385-1389.

Boileau, C., Martel-Pelletier, J., Jouzeau, J. Y., Netter, P., Moldovan, F., Laufer, S., Tries, S. and Pelletier, J. P. (2002). Licofelone (ML-3000), a dual inhibitor of 5-lipoxygenase and cyclooxygenase, reduces the level of cartilage chondrocyte death in vivo in experimental dog osteoarthritis: inhibition of pro-apoptotic factors. J. Rheumatol. 29, 1446-1453.

Chung, I. M., Khanh, T. D., Lee, O. K. and Ahmad, A. (2007). Chemical constituents from ajwain seeds (Trachyspermum ammi) and inhibitory acitivity of thymol, lupeol and fatty acids on barnyard grass and radish seeds. Asian J. Chem. 19, 1524-1534.

Foo, L. Y. and Karchesy, J. J. (1989). Polyphenolic glycosides from Douglas fir inner bark. Phytochemistry. 28, 1237-1240.

Gulliksson, M., Palmberg, L., Nilsson, G., Ahlstedt, S. and Kumlin, M. (2006). Release of prostaglandin D2 and leukotriene C4 in response to hyperosmolar stimulation of mast cells. Allergy. 61, 1473-1479.

Hisashi, K. and Haruo, O. (1989). Configurational studies on hydroxy groups at C-2, 3 and 23 or 24 of oleanene and ursene-type triterpenes by NMR spectroscopy. Phytochemistry. 28, 1703-1710.

Inoshiri, S., Sasaki, M., Kohda, H., Otsuka, H. and Yamasaki, K.
(1987). Aromatic glycosides from Berchemia racemosa. Phytochemistry. 26, 2811-2814.

Ishimaru, K., Nonaka, G. I. and Nishioka, I. (1987). Flavan-3-ol and procyanidin glycosides from Quercus miyagii. Phytochemistry. 26, 1167-1170.

Jin, M. H., Bae, K, H., Son, J. K. and Chang, H. W. (2009). Anti-inflammatory compounds from the leaves of Ailanthus altissima. Biomol. Therap. 17, 86-91.

Jin, U. H., Lee, D. Y., Kim, D. S., Lee, I. S. and Kim, C. H. (2006). Induction of mitochondria-mediated apoptosis by methanol fraction of Ulmus davidiana Planch (Ulmaceae) in U87 glioblastoma cells. Environ. Toxicol. Pharmaco. 22, 136-141.

Jin, U. H., Suh, S. J., Park, S. D., Kim, K. S., Kwon, D. Y. and Kim, C. H. (2008). Inhibition of mouse osteoblast proliferation and prostaglandin E2 synthesis by Ulmus davidiana Planch (Ulmaceae). Food Chem. Toxicol. 46, 2135-2142.

Jippo, T., Kobayashi, Y., Sato, H., Hattori, A., Takeuchi, H., Sugimoto, K. and Shigekawa, M. (2009). Inhibitory effects of guarana seed extract on passive cutaneous anaphylaxis and mast cell degranulation. Biosci. Biotechnol. Biochem. 73, 2110-2112.

Jun, C. D., Pae, H. O., Kim, Y. C., Jeong, S. J., Yoo, J. C., Lee, E. J., Choi, B. M., Chae, S. W., Park, R. K. and Chung, H. T. (1998). Inhibition of nitric oxide synthesis by butanol fraction of the methanol extract of Ulmus davidiana in murine macrophages. J. Ethnopharmacol. 62, 129-135.

Kang, S. K., Kim, K. S., Byun, Y. S., Suh, S. J., Jin, U. H., Kim, K. H., Lee, I. S. and Kim, C. H. (2006). Effects of Ulmus davidiana Planch on mineralization, bone morphogenetic protein-2, alkaline phosphatase type I collagen, and collagenase-1 in bone cells. In Vitro Cell. Develop. Biol. Animal 42, 225-229.

Kim, H. J., Yeom, S. H., Kim, M. K., Shim, J. G., Lim, H. W. and Lee, M. W. (2004). Nitric oxide and prostaglandin E2 synthesis inhibitory activities of flavonoids from the barks of Ulmus macrocarpa. Nat. Prod. Sci. 10, 344-346.

Kohler, N., Wray, V. and Winterhalter, P. (2008). Preparative isolation of procyanidins from grap seed extracts by highspeed counter-current chromatography. J. Chromato. A. 1177, 114-125.

Lavaud, C., Massiot, G., Barrera, J. B., Moretti, C. and Le MenOlivier, L. (1994). Triterpene saponins from Myrsine pellucida. Phytochemistry 37, 1671-1677.

Lee, M. K., Sung, S. H., Lee, H. S., Cho, J. H. and Kim, Y. C. (2001). Lignan and neolignan glycosides from Ulmus davidiana var. japonica. Arch. Pharm. Res. 24, 198-201.

Lee, S. H., Son, M. J., Ju, H, K., Lin, C, X., Moon, T. C., Choi, H. G., Son, J. K. and Chang, H. W. (2004). Dual inhibition of cyclooxygenases-2 and 5-lipoxygenase by deoxypodophyllotoxin (anthricin) in mouse bone marrow-derived mast cells. Biol. Pharm. Bull. 27, 786-788.

Li, S., Chen, R. Y. and Yu, D. Q. (2007). Study on chemical constituents of Myricaria paniculata I. Zhongguo Zhong Yao Za Zhi. 32, 403-406.

Martel-Pelletier, J., Lajeunesse, D., Reboul, P., Pelletier, J. P. (2003) Therapeutic role of dual inhibitors of 5-LOX and COX, selective and non-selective non-steroidal anti-inflammatory drugs. Ann. Rheum. Dis. 62, 501-509.

Metcalfe, D. D., Peavy, R. D. and Gilfillan, A. M. (2009) Mechanisms of mast cell signaling in anaphylaxis. J. Allergy Clin. 
Immunol. 124, 639-646.

Mitchell, J. A. and Warner, T. D. (2006) COX isoforms in the cardiovascular system: understanding the activities of nonsteroidal anti-inflammatory drugs. Nat. Rev. Drug Discov. 5, 75-86.

Moon, T. C., Murakami, M., Kudo, I., Son, K. H., Kim, H. P. and Chang, H. W. (1999). A new class of COX-2 inhibitor, rutaecarpine from Evodia rutaecarpa. Inflamm. Res. 48, 621-625.

Moon, Y. H. and Rim, G. R. (1995). Studies on the constituents of Ulmus parvifolia. Korean J. Pharmacognosy. 26, 1-7.

Murakami, M., Matsumoto, R., Austen, K. F. and Arm, J. P. (1994). Prostaglandin endoperoxide synthase-1 and -2 couple to different transmembrane stimuli to generate prostaglandin D2 in mouse bone marrow-derived mast cells. J. Biol. Chem. 269, 22269-22275.

Na, M. K., An, R. B., Lee, S. M., Min, B. S., Kim, Y. H., Bae, K. H. and Kang, S. S. (2002). Antioxidant compounds from the stem bark of Sorbus commixta. Nat. Prod. Sci. 8, 26-29.

Nahrstedt, A., Proksch, P. and Conn, E. E. (1987). (-)-Catechin, flavonol glycosides and flavones from Chamaebatia foliolosa. Phytochemistry. 26, 1546-1547.

Nawamaki, K. and Kuroyanagi, M. (1996). Sesquiterpenoids from Acorus calamus as germination inhibitors. Phytochemistry 43, 1175-1182.

Ono, E., Taniguchi, M., Mita, H., Fukutomi, Y., Higashi, N., Miyazaki, E., Kumamoto, T. and Akiyama, K. (2009) Increased production of cysteinyl leukotrienes and prostaglandin D2 during human anaphylaxis. Clin. Exp. Allergy 39, 72-80.

Pabst, A., Barron, D., Semon, E. and Schreier, P. (1992). Two diastereomeric 3 -oxo- $\alpha$-ionol- $\beta$-glucosides from raspberry fruit. Phytochemistry 31, 1649-1652.

Rotondo, S., Dell'Elba, G., Krauze-Brzósko, K., Manarini, S., Martelli, N., Pecce, R., Evangelista, V. and Cerletti, C. (2002). Licofelone, a dual lipoxygenase-cyclooxygenase inhibitor, downregulates polymorphonuclear leukocyte and platelet function. Eur. J. Pharmacol. 453, 131-139.

Rouzer, C. A. and Marnett, L. J. (2009) Cyclooxygenases: structural and functional insights. J. Lipid Res. 50, 29-34.

Sang, S., Kikuzaki, H., Lapsley, K., Rosen, R. T., Nakatani, N. and Ho, C. T. (2002). Sphingolipid and other constituents from almond nuts (Prunus amygdalus Batsch). J. Agric. Food Chem. 50, 4709-4712.

Seebacher, W., Simic, N., Weis, R., Saf, R. and Kunert, O. (2003). Complete assignments of ${ }^{1} \mathrm{H}$ and ${ }^{13} \mathrm{C}$ NMR reso- nances of oleanolic acid, 18-oleanolic acid, ursolic acid and their 11-oxo derivatives. Magn. Res. Chem. 41, 636-638.

Siddiqui, A. A., Wani, S. M., Rajesh, R. and Alagarsamy, V. (2006). Phytochemical and pharmacological investigation of Hibiscus rosasinensis Linn. Indian J. Pharm. Sci. 68, 588593.

Smite, E., Pan, H. and Lundgren, L. N. (1995). Lignan glycosides from inner bark of Betula pendula. Phytochemistry 40, 341-343.

Son, J. K., Son, M. J., Lee, E. K., Moon, T. C., Son, K. H., Kim, C. H., Kim, H. P., Kang, S. S. and Chang, H. W. (2005) Ginkgetin, a biflavone from Ginko biloba leaves, inhibits cyclooxygenases-2 and 5-lipoxygenase in mouse bone marrow-derived mast cells. Biol. Pharm. Bull. 28, 2181-2184.

Song, I. K., Kim, K. S., Suh, S. J., Kim, M. S., Kwon, D. Y., Kim, S. L. and Kim, C. H. (2007). Anti-inflammatory effect of Ulmus davidiana Planch on collagen-induced inflammation in rats. Environ. Toxicol. Pharmacol. 23, 102-110.

Suh, S. J., Yun, W. S., Kim, K. S., Jin, U. H., Kim, J. K., Kim, M. S., Kwon, D. Y. and Kim, C. H. (2007). Stimulative effect of Ulmus davidiana Planch (Ulmaceae) on osteoblastic MC3T3-E1 cells. J. Ethnopharmacol. 109, 480-485.

Theoharides, T. C., Kempuraj, D., Tagen, M., Conti, P. and Kalogeromitros, D. (2007) Differential release of mast cell mediators and the pathogenesis of inflammation. Immunol. Rev. 217, 65-78.

Umlauf, D., Zapp, J., Becker, H. and Adam, K. P. (2004). Biosynthesis of the irregular monoterpene artemisia ketone, the sesquiterpene germacrene $D$ and other isoprenoids in Tanacetum vulgare L. (Asteraceae). Phytochemistry. 65, 2463-2470.

Wang, D., Xia, M. and Cui, Z. (2006). New triterpenoids isolated from the root bark of Ulmus pumila L. Chem. Pharm. Bull. 54, 775-778.

Yoshinari, K., Sashida, Y. and Shimomura, H. (1989). Two new lignan xylosides from the barks of Prunus ssiori and Prunus padus. Chem. Pharm. Bull. 37, 3301-3303.

Yumiko, K., Toshihiro, A., Ken, Y., Michio, T. and Toshitake, T. (1995). Structures of five hydroxylated sterols from the seeds of Trichosanthes kirilowii Maxim. Chem. Pharm. Bull. 43, 1813-1817.

Zhang, C. Z., Xu, X. Z. and Li, C. (1996). Fructosides from Cynomorium songaricum. Phytochemistry. 41, 975-976. 